ХОМУТЯНСькИЙ в. В., старший викладач кафедри адміністративного права і процесу та митної безпеки (Університет державної фіскальної служби України)

УДК 342.95

DOI https://doi.org/10.32842/2078-3736-2019-6-2-12

\title{
СУЧАСНІ ПРОБЛЕМИ ЮРИДИЧНОЇ КВАЛІФІКАЦІЇ ПОРУШЕНЬ МИТНИХ ПРАВИЛ
}

Стаття присвячена висвітленню сучасних проблем юридичної кваліфікації порушень митних правил, обгрунтуванню напрямів вдосконалення чинного законодавства у цій сфері, в тому числі уточненню актуальних норм, кваліфікація яких має проблемний характер. Обгрунтовано, що класифікація митних адміністративних правопорушень насамперед має значення для практичної діяльності митних та судових органів, для правильної кваліфікації діянь, які порушують митні правила та відмежування їх від інших правопорушень.

Визначено, що порушення митних правил посідають самостійне місце у структурі адміністративних правопорушень, оскільки, по-перше, регламентуються окремим законодавчим актом - Митним кодексом України, по-друге, родовим (видовим) об' єктом посягання виступає встановлений порядок переміщення товарів та транспортних засобів через митний кордон України, по-третє, порядок притягнення до адміністративної відповідальності регламентується Митним кодексом України, а в частині, яка не врегульована ним, - відповідно до законодавства України. Обгрунтовано, що під час накладення адміністративних стягнень необхідно в кожному конкретному випадку враховувати такі фактори: факт вчинення протиправного діяння; тривалість та/або безперервність вчинення протиправного діяння; встановлення моменту виявлення правопорушення; встановлення моменту настання шкідливих наслідків.

У результаті проведеного дослідження визначено, що перспективи розвитку юридичної кваліфікації порушень митних правил зумовлюються тим, що в Україні ще не повністю врегульовано питання, пов'язані з визначенням, правомірністю та співвідношенням складників порушень митних правил, які повинні чітко регламентуватися національним законодавством для дієвості виявлення і припинення порушень митного законодавства. У зв'язку з цим правозастосовна практика митних органів під час кваліфікації деяких ПМП потребує законодавчого вдосконалення.

Ключові слова: митна діяльність, законність, правопорушення, юридична кваліфікачія, юридична відповідальність.

The article is devoted to covering modern problems of legal qualification of violations of customs rules, substantiation of directions of improvement of the current legislation in this field, including clarification of actual norms, qualification of which is problematic. It is substantiated that the classification of customs administrative offenses, first of all, is important for the practical activity of customs and judicial authorities, for the proper qualification of actions that violate customs rules and differentiate them from other offenses.

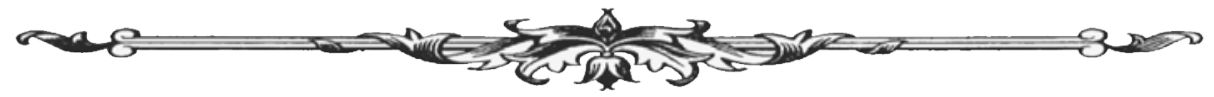


It has been determined that violations of customs rules occupy an independent place in the structure of administrative offenses, because, first, they are regulated by a separate legislative act - the Customs Code of Ukraine, and secondly, the generic (species) object of assault is the established procedure for the movement of goods and vehicles. the customs border of Ukraine, third, the procedure for bringing to administrative responsibility is regulated by the Customs Code of Ukraine, and in the part that is not regulated by it - in accordance with the legislation of Ukraine. It is substantiated that when imposing administrative penalties it is necessary to take into account in each case the following factors: the fact of committing an unlawful act; the duration and / or continuity of the offense; establishment of the moment of detection of the offense; establishment of the moment of occurrence of harmful consequences.

As a result of the conducted research, it is determined that the prospects for the development of the legal qualification of violations of customs rules are due to the fact that in Ukraine the issues related to the definition, legality and correlation of constituents of violations of customs rules, which should be clearly regulated by national legislation for detection and effectiveness, are still not fully settled cessation of violations of customs legislation. For this reason, the law enforcement practice of the customs authorities in the qualification of some violation of customs rules requires legislative improvement.

Key words: customs, legality, offense, legal qualification, legal responsibility.

Вступ. На сучасному етапі у правовій системі України постійно підвищується роль митного законодавства як однієї з найбільш динамічних галузей вітчизняного законодавства, яка суттєво впливає на формування нової системи правовідносин, становлення України як суверенної, незалежної, демократичної, правової держави, суб'єктів зовнішньоекономічних процесів і міжнародної торгівлі. Для рівноправної участі нашої держави як асоційованого члена Європейського Союзу у Світовій організації торгівлі, набуття реального статусу країни з ринковою економікою необхідно покращити економічну ситуацію. Вказані процеси неодмінно супроводжуються активним використанням митних засобів державного регулювання і постійними порушеннями митних правил.

Порушення митних правил негативно впливає на економічні інтереси нашої держави та, як наслідок, на рівень життя населення. Територіальне розміщення України, де перетинаються торговельні шляхи з півночі на південь, зі сходу на захід, робить ііі привабливою не лише для зарубіжних партнерів, але й для так званих прибічників незаконного бізнесу.

Суб’єкти господарювання і фізичні особи, які переміщують товари й транспортні засоби через державний кордон, мають дотримуватись установленого порядку переміщення через митний кордон України. Однак більшість суб'єктів ЗЕД для власного збагачення намагаються обійти обов'язкові процедури митного контролю і митного оформлення 3 метою уникнення сплати податків і зборів до бюджету під час переміщення товарів та інших предметів через митний кордон. Тому головним завданням митних органів є протидія митним правопорушенням і боротьба з контрабандою.

Огляд останніх досліджень і публікацій. Проблеми юридичної кваліфікації митних правопорушень, зокрема їх виокремлення, досліджені у роботах таких науковців, як Є.В. Додін, В.Я. Настюк, В.В. Прокопенко, І.О. Федотова, та інших. Втім, окремі проблеми, що розглядатимуться у цій статті, залишаються невирішеними.

Постановка завдання. Метою цієї статті є висвітлення сучасних проблем юридичної кваліфікації порушень митних правил, обгрунтування напрямів вдосконалення чинного законодавства у цій сфері, в тому числі уточнення актуальних норм, кваліфікація яких має проблемний характер.

Результати дослідження. Загальновизнаною класифікацією правопорушень є їх класифікація за ступенем суспільної небезпеки та завданої шкоди. Залежно від міри суспільної небезпеки правопорушення поділяють на [1, с. 366]:

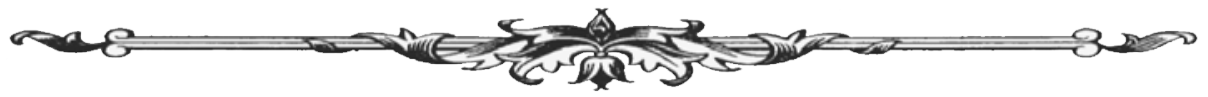


- злочини - передбачені і заборонені кримінальним законодавством, протиправні суспільно небезпечні діяння, які спричиняють чи можуть спричинити істотну шкоду певним охоронюваним державою суспільним відносинам;

- проступки - протиправні, винні діяння, які не настільки небезпечні, як злочини, але завдають шкоду особі, суспільству, державі, вчиняються в усіх врегульованих правом сферах суспільного життя, мають різні об’єкти посягання і викликають юридичні наслідки за їх вчинення - стягнення.

Щодо митних правопорушень, то до злочинів, що вчиняються в галузі митної справи, належать діяння, передбачені Кримінальним кодексом України від № (далі - КК України) [2]. Так, у статті 201 КК України під контрабандою розуміється переміщення через митний кордон України поза митним контролем або з приховуванням від митного контролю культурних цінностей, отруйних, сильнодіючих, вибухових речовин, радіоактивних матеріалів, зброї або боєприпасів (крім гладкоствольної мисливської зброї або бойових припасів до неї), частин вогнепальної нарізної зброї, а також спеціальних технічних засобів негласного отримання інформації. Видом контрабанди є переміщення через митний кордон України поза митним контролем або з приховуванням від митного контролю лісоматеріалів або пиломатеріалів цінних та рідкісних порід дерев, лісоматеріалів необроблених, а також інших лісоматеріалів, заборонених до вивозу за межі митної території України (ст. 201-1 КК України). Окремим видом можна вважати також контрабанду наркотичних засобів, психотропних речовин, їх аналогів чи прекурсорів або фальсифікованих лікарських засобів (ст. 305 КК України) [2].

Найпоширенішим видом порушень у митній сфері $є$ порушення митних правил. Відповідно до ст. 226 Основ митного законодавства країн - учасниць СНД порушенням митних правил визнається протиправна дія (бездіяльність) особи, що посягає на встановлений національним законодавством і міжнародними договорами держави порядок переміщення через митний кордон держави товарів і транспортних засобів, здійснення їх митного контролю і митного оформлення, обкладання митними платежами та їх сплати, надання митних пільг і користування ними, а також на нормальну діяльність митних органів, за які національним законодавством передбачена відповідальність [3].

Т.В. Курило наводить таке визначення порушення митних правил: «порушення митних правил - це протиправна, винна (навмисна або необережна) дія чи бездіяльність, яка посягає на:

- встановлений порядок переміщення через митний кордон України товарів і транспортних засобів;

- здійснення митного оформлення і митного контролю за ними;

- обкладання митом, податками та митними зборами товарів і транспортних засобів» $[4$, с. 100$]$.

Можна дійти висновку, що залежно від того, на який саме порядок посягає те чи інше порушення митних правил, Т.В. Курило відносить його до однієї із трьох груп.

Основною відмінною рисою порушень митних правил від митних злочинів $є$ їх менша суспільна небезпека. Склади правопорушень встановлюються в законодавстві України з метою правової охорони одних і тих же суспільних цінностей, благ у галузі митної справи. На думку О.В. Константи, інститут порушень митних правил, порівняно із засобами кримінального права, відіграє «додаткову» роль для цілей забезпечення митних інтересів держави [5, c. 8-9].

Порушення митних правил (або, як визначають ці дії міжнародні конвенції з питань митної справи, - порушення митного законодавства) - це митна злочинність та митна деліктність, що займає особливе місце в системі протиправної поведінки, загрожує не тільки національній, але й міжнародній безпеці, незалежно від того, скоєні ці діяння транснаціональними організованими злочинними угрупуваннями або однією фізичною особою; резидентом чи нерезидентом нашої країни тощо. Декриміналізація деяких митних злочинів, або їх гуманізація, яка зроблена законом «Про внесення змін до деяких законодавчих актів України (щодо гуманізації відповідальності за правопорушення у сфері господарської діяльності)» [6],

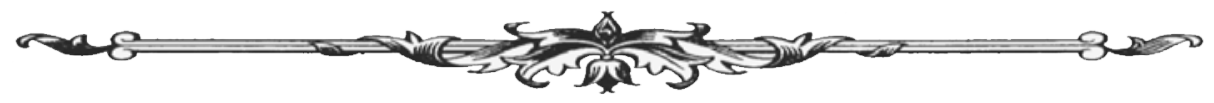


в жодному разі не змінює стану їх суспільної небезпеки. Вони як були, так і залишаються діяннями, визнаними світовим суспільством як такі, що «становлять загрозу економічним, соціальним та фіскальним інтересам держав та законним інтересам торгівлі» [7].

Аналізуючи сучасні погляди на це питання, робимо висновок, що порушення митних правил належать до категорії адміністративних правопорушень.

Відповідно до ст. 458 Митного кодексу України (далі - МКУ) порушення митних правил (ПМП) є адміністративним правопорушенням, яке являє собою протиправні, винні (умисні або з необережності) дії чи бездіяльність, що посягають на встановлений МКУ та іншими актами законодавства України порядок переміщення товарів, транспортних засобів комерційного призначення через митний кордон України, пред’явлення їх органам доходів і зборів для проведення митного контролю та митного оформлення, а також здійснення операцій з товарами, що перебувають під митним контролем або контроль за якими покладено на органи доходів і зборів МКУ чи іншими законами України, і за які Митним кодексом передбачена адміністративна відповідальність [8].

Зазначене визначення з деякими особливостями фактично дублює визначення адміністративного правопорушення (проступку), що міститься в ст.9 КпАП України.

ПМП має свій юридичний склад. Під юридичним складом порушення митних правил передбачають визначену нормами митного права сукупність загальних елементів, за наявності яких ту або іншу дію можна вважати порушенням митних правил [9, с. 202-203]. Це два елементи, що характеризують зовнішню сторону правопорушення, - об'єкт, об'єктивна сторона, та два елементи, що характеризують внутрішню сторону правопорушення, - суб' єкт, суб' єктивна сторона [10, с. 263-266].

Отже, на основі аналізу визначень поняття «порушення митних правил» ми зробили висновок, що порушення митних правил - це діяння суб'єктів митних правовідносин, для яких характерні такі обов'язкові ознаки:

- протиправність (порушення конкретної норми Митного кодексу України);

- винність (умисне протиправне діяння або протиправне діяння 3 необережності);

- караність (передбачена відповідальність Митним кодексом України за вчинене порушення).

Протиправність - це юридична оцінка суспільної небезпеки правопорушення. Вона виявляється в тому, що порушення митних правил визнається таким тоді, коли воно передбачене чинним законодавством, тобто це діяння, яке завжди посягає на встановлені нормативно-правовими актами загальнообов’язкові правила.

Винність характеризує психологічне ставлення особи до вчиненої дії чи бездіяльності та їі наслідків, виражене у формі умислу або необережності. Винність - діяння, яке $\epsilon$ проявом волі і свідомості, завжди є вчиненим умисно або з необережності.

Караність - протиправне винне діяння є адміністративним правопорушенням винятково у разі, коли законодавством за його вчинення передбачено адміністративну відповідальність;

Діяння - дія чи бездіяльність, інші прояви психічної діяльності людини (думки, бажання тощо) до ознак адміністративного правопорушення не належать; суспільний ризик також зустрічається в науці як антигромадська спрямованість, суспільна небезпека, суспільна шкідливість [11, с. 18].

У результаті дослідження встановлено, що порушення митних правил посідають самостійне місце у структурі адміністративних правопорушень, оскільки, по-перше, регламентуються окремим законодавчим актом - Митним кодексом України, по-друге, родовим (видовим) об'єктом посягання виступає встановлений порядок переміщення товарів та транспортних засобів через митний кордон України, по-третє, порядок притягнення до адміністративної відповідальності регламентується Митним кодексом України, а в частині, яка не врегульована ним, - відповідно до законодавства України.

Під структурою порушень митних правил пропонується розуміти питому вагу і співвідношення усередині зазначеного масиву різних видів порушень митних правил.

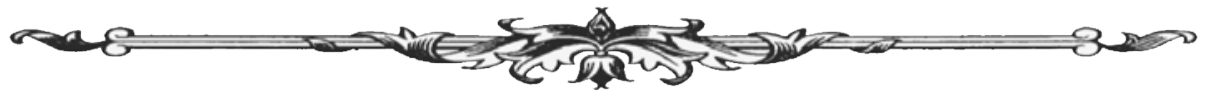


Порушення митних правил є адміністративними правопорушеннями, які посідають самостійне місце у структурі адміністративних правопорушень, оскільки їх об'єднує загальний об'єкт посягання - суспільні відносини у сфері митної справи - особливій сфері суспільного життя.

Поширеною є класифікація порушень митних правил за об’єктом посягання. За цим критерієм у науці розрізняють чотири об'єкти посягання на суспільні відносини у сфері державної митної справи, а отже, чотири групи порушень митних правил, зокрема, правопорушення, пов'язані з такими правовідносинами:

- здійснення митного контролю (статті 468, 470, 471, 474, 475, 479, 484 Митного кодексу України);

- здійснення митного оформлення (статті 469, 472, 478 Митного кодексу України);

- переміщення через митний кордон товарів і транспортних засобів (статті 473, 476, 477, 480, 481, 482, 483 Митного кодексу України);

- сплати митних платежів (стаття 485 Митного кодексу України).

При цьому класифікація порушень митних правил за критерієм об'єкта посягання має доволі умовний характер, оскільки правопорушення може посягати не лише на порядок митного контролю, а й на порядок митного оформлення. Як приклад у статті 482 Митного кодексу України «Переміщення або дії, спрямовані на переміщення товарів, транспортних засобів комерційного призначення через митний кордон України поза митним контролем» діяння водночас посягає на встановлений порядок переміщення товарів і транспортних засобів через митний кордон та на порядок митного контролю, тому що переміщення поза митним контролем $є$ одним із способів незаконного переміщення.

Крім того, стаття 485 Митного кодексу України є досить поширеною щодо правозастосовної діяльності правоохоронного блоку органів доходів і зборів, оскільки одним із завдань органів доходів і зборів $є$ забезпечення справляння митних платежів, контроль правильності обчислення, своєчасності та повноти їх сплати, застосування заходів щодо їх примусового стягнення у межах повноважень, визначених цим кодексом, Податковим кодексом та іншими актами законодавства України, попри те, що у понятті «Порушення митних правил», передбаченому статтею 458 Митного кодексу України, відсутня норма про те, що об’єктом посягання такого виду правопорушення є порядок сплати митних платежів.

Порушення митних правил можна класифікувати 3 урахуванням ознак об'єктивної сторони. Відповідно до форми вчинення протиправних діянь розрізняють правопорушення, що вчиняються шляхом:

- дії, тобто здійснення тих чи інших дій (статті 468, 469, 471, 473, 474, 476, 477, 478, 482, 483, 484, 485 Митного кодексу України);

- бездіяльності - утримання від виконання тих чи інших дій (статті 470, 472, 475, 479, 480, 481 Митного кодексу України).

Митним кодексом України передбачено два види суб'єктів порушень митних правил: загальний та спеціальний, при цьому санкції статей 468-485 Митного кодексу України не розрізняють окремі види покарання для фізичних (приватних) осіб та посадових осіб суб'єктів господарювання. Таким чином, залежно від суб'єктів порушення митних правил вони можуть бути поділені на:

- порушення, суб'єктами яких можуть бути будь-які фізичні (приватні) особи, у тому числі фізичні особи - посадові особи суб'єктів господарювання (статті 468, 469, 470, 471, 472, 473, 474, 476, 477, 481, 482, 483, 484, 485 Митного кодексу України);

- порушення, суб'єктами яких можуть бути тільки спеціальні суб'єкти - посадові особи підприємств (статті 475, 478, 479, 480 Митного кодексу України).

Залежно від наявності шкідливих наслідків виділяються:

- порушення митних правил з формальним складом (статті 468, 469, 470, 474, 475, 477, 478, 479, 480, 481 Митного кодексу України);

- порушення митних правил з матеріальним складом (статті 471, 472, 473, 476, 482, 483, 484, 485 Митного кодексу України).

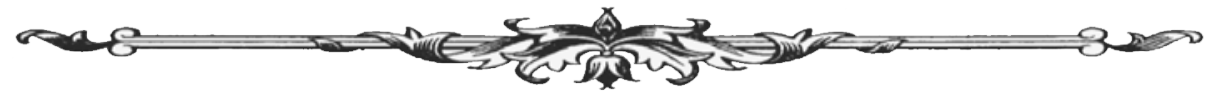


Залежно від обчислення строків накладення адміністративних стягнень порушення митних правил також поділяються на: України);

- триваючі (статті 469, 477, 478, 479, 480, 481, 482, 483, 484, 485 Митного кодексу

- порушення, що мають разовий характер (статті 468, 470, 471, 472, 473, 474, 475 , 476 Митного кодексу України).

Митний кодекс України (далі - МК України) [8] у ст. 467 «Строки накладення адміністративних стягнень у справах про порушення митних правил» встановлює строки розгляду митними органами справ про триваючі порушення митних правил із застосуванням цих строків до ст. 469, 477-481, 485. Строк адміністративного стягнення - не пізніше, ніж через шість місяців 3 дня виявлення цих правопорушень. Митний кодекс України в ст. 268 передбачає можливість допущення у митній декларації помилок та право декларанта на їх виправлення. Але якщо особа систематично (більше двох разів протягом місяця) допускає у митній декларації помилки (крім орфографічних помилок), митний орган застосовує до такої особи санкції, передбачені ст. 460 Митного Кодексу. Таким чином, не виключається можливість застосування положень щодо триваючого правопорушення за систематичного допущення помилок у митній декларації.

При цьому у різних наукових дослідженнях, що стосуються державної митної справи, принципи класифікації порушень митних правил адаптуються до предмету дослідження з метою забезпечення втілення новизни у правозастосовній діяльності державних та судових органів, зокрема, щодо профілактики порушень митних правил та притягнення винних до відповідальності $[12 ; 13 ; 14]$.

Така класифікація порушень митних правил не є винятковою та може бути доповнена іншими критеріями, залежно від напряму дослідження.

Таким чином, із запропонованих критеріїв класифікації можемо зробити висновок про те, що класифікація митних адміністративних правопорушень передусім має значення для практичної діяльності митних та судових органів, для правильної кваліфікації діянь, які порушують митні правила та відмежування їх від інших правопорушень.

Висновки. Проведене дослідження надає підстави для таких висновків. Класифікація митних адміністративних правопорушень насамперед має значення для практичної діяльності митних та судових органів, для правильної кваліфікації діянь, які порушують митні правила, та відмежування їх від інших правопорушень.

Порушення митних правил посідають самостійне місце у структурі адміністративних правопорушень, оскільки, по-перше, регламентуються окремим законодавчим актом - Митним кодексом України, по-друге, родовим (видовим) об'єктом посягання виступає встановлений порядок переміщення товарів та транспортних засобів через митний кордон України, по-третє, порядок притягнення до адміністративної відповідальності регламентується Митним кодексом України, а в частині, яка не врегульована ним, - відповідно до законодавства України.

Під час накладення адміністративних стягнень необхідно в кожному конкретному випадку враховувати такі фактори:

- факт вчинення протиправного діяння;

- тривалість та/або безперервність вчинення протиправного діяння;

- встановлення моменту виявлення правопорушення;

- встановлення моменту настання шкідливих наслідків.

Перспективи розвитку юридичної кваліфікації порушень митних правил зумовлюються тим, що в Україні ще не повністю врегульовано питання, пов’язані з визначенням, правомірністю та співвідношенням складників порушень митних правил, які повинні чітко регламентуватися національним законодавством для дієвості виявлення і припинення порушень митного законодавства. У зв'язку з цим правозастосовна практика митних органів під час кваліфікації деяких ПМП потребує законодавчого вдосконалення.

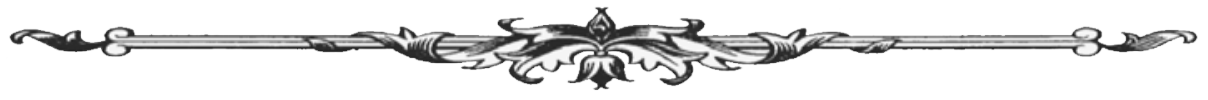




\section{Список використаних джерел:}

1. Загальна теорія держави і права: підруч. / М.В. Цвік, О.В. Петришин, Л.В. Авраменко та ін. Харків : Право, 2009. 584 с.

2. Кримінальний кодекс України: ред. від 03.09.2017 №2114-19. Відомості Верховної Ради Украӥни. 2001. № 25-26. С. 131. URL: http://zakon5.rada.gov.ua/laws/show/2341-14 (дата звернення 12.11.2019).

3. Рішення про Основи митного законодавства країн - учасниць Співдружності Незалежних Держав від 10.02.1995 p. URL: http://zakon.rada.gov.ua/cgi-bin/laws/main. cgi?nreg=997_509 (дата звернення 12.11.2019).

4. Курило Т.В. Митне право України : навч. посібник. «Новий світ/2000», 2007. 240 с.

5. Константа О.В. Адміністративно-правові заходи боротьби з порушеннями митних правил : автореф. дис. ... канд. юрид. наук : 12.00.07. Харків, 2008. 120 с.

6. Про внесення змін до деяких законодавчих актів України (щодо гуманізації відповідальності за правопорушення у сфері господарської діяльності): Закон України від 27.09.2011 p. реєстраційний номер 9221. URL: http://w1.c1.rada.gov.ua/pls/ zweb_n/webproc4_1?id=\&pf3511=41271 (дата звернення 10.11.2019)

7. Міжнародна конвенція про взаємну адміністративну допомогу у відверненні, розслідуванні та припинення порушень митного законодавства від 09.06.1977 p. URL: http://zakon2.rada.gov.ua/laws/show/995_926 (дата звернення 12.11.2019)

8. Митний кодекс України від 26.07.2017 № 4495-17. Відомості Верховної Ради України (ВВР). 2012, № 44-45, № 46-47, № 48. с. 552.

9. Митне право України : навч. посібн. / В.В. Ченцов, С.В. Кувакін, А.В. Мазур, та ін. ; за ред. В.В. Ченцова. Київ, 2007. 283 с

10. Актуальні питання теорії та практики митної справи : монографія / за заг. ред. І.Г. Бережнюка. Хмельницький : ПП Мельник А.А., 2013. 428 с. C. $17-29$.

11. Додін Є.В. Митна злочинність: поняття та структура. Митна справа. 2010. № 3 (69).

12.Баранов С.О. Попередження адміністративних правопорушень, що посягають на митні відносини : дис.. ... канд.. юрид наук : 12.00.07. Київський національний університет ім. Тараса Шевченка. 2002. 227 с.

13. Константа О.В. Адміністративно-правові заходи боротьби з порушеннями митних правил : дис. ... канд. юрид. наук : 12.00.07. Національна юридична академія України імені Ярослава Мудрого. Харків, 2008. 223 с.

14. Шевченко В.М. Правила переміщення через митний кордон України підакцизних товарів та відповідальність за їх порушення : дис. канд. юрид. наук : 12.00.07. Київський університет ім. Тараса Шевченка. Київ, 2000. 200 с.

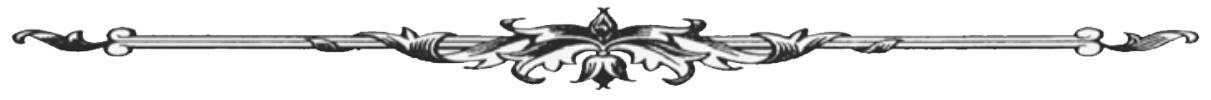

